\title{
Propagation and Production of False Rosemary 1
}

\section{Mack Thetford and Debbie Miller² \\ Introduction}

False rosemary (Conradina canescens Gray [Lamiaceae]) is common to coastal areas of west Florida and is known to contribute to beach mouse habitat. This species can be considered a drought-tolerant landscape plant. Coastal homeowners interested in diminished water and fertilizer application may consider the use of false rosemary in landscapes of coastal developments.

False rosemary occurs in dunes and scrub areas extending from Florida's Escambia to Wakulla counties (Clewell 1985). It may be used for beach projects requiring planting on the back side of primary dunes, or any side of secondary dunes and is also a candidate for use in commercial or home landscapes (Figure 1). The shrub is pubescent with numerous stiffly erect or spreading branches and small, revolute leaves $1 \mathrm{~cm}(0.39$ inch $)$ or less in length (Bell and Taylor 1982). Flowering occurs from March to November with small clusters of white to lavender two-lipped, zygomorphic flowers. Although false rosemary is very common in its native range, it is endemic to only a small area of west Florida and adjacent Alabama. Demand for a diversity of coastal species has increased following hurricane activity and false rosemary is an excellent candidate for restoration or for including additional native flowering plants to a coastal landscape.

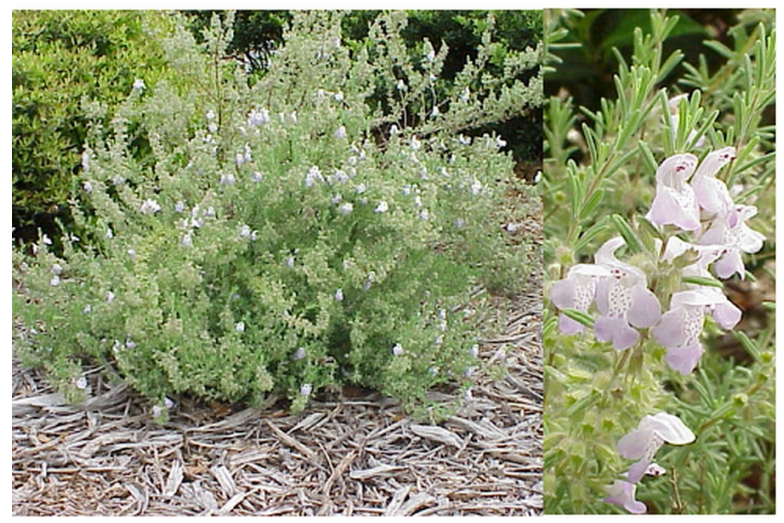

Figure 1. False rosemary (Conradina canescens) shoot and flower detail and entire plant growing in a non-irrigated Florida landscape. Credits: Photo by Mack Thetford.

\section{Propagation}

Softwood cuttings may be collected during the growing season and placed in plastic bags or stored in a cooler for transport. Prepare cuttings from nonbranched terminal shoots cut to a length of 4 inches for uniformity. Remove the foliage from the

1. This document is Fact Sheet ENH 973, from the Environmental Horticulture Department and the Wildife Ecology and Conservation Department, Florida Cooperative Extension Service, Institute of Food and Agricultural Sciences, University of Florida. Publication date: March 25, 2004. Please visit the EDIS web site at http://edis.ifas.ufl.edu.

2. Mack Thetford, associate professor, Environmental Horticulture Department; Deborah "Debbie" L. Miller, associate professor, Wildlife Ecology and Conservation Department, Cooperative Extension Service, Institute of Food and Agricultural Sciences, West Florida Research and Education Center, University of Florida, 5988 Highway 90, Bldg. 4900, Milton, FL 32583. For more information, contact your county Cooperative Extension Service office.

The Institute of Food and Agricultural Sciences (IFAS) is an Equal Employment Opportunity - Affirmative Action Employer authorized to provide research, educational information and other services only to individuals and institutions that function without regard to race, creed, color, religion, age, disability, sex, sexual orientation, marital status, national origin, political opinions or affiliations. For information on obtaining other extension publications, contact your county Cooperative Extension Service office. Florida Cooperative Extension Service / Institute of Food and Agricultural Sciences / University of Florida / Larry R. Arrington, Interim Dean 
basal $1 / 2$ inch. Treat the base of each cutting with a quick dip of an auxin solution for 1 second followed by 15 minutes of air drying or treat with a talc-based auxin prior to insertion to a $1 / 2$ to $3 / 4$ inch depth. Cuttings may be propagated in small pots or nursery flats with inserts divided into individual cells. Well-drained propagation mixes should be used to ensure sufficient oxygen in the rooting zone.

Research has shown rooting success with pinebark-based substrates or potting mixes containing a mixture of sphagnum peat moss, horticultural perlite and vermiculite (Thetford and Miller 2002). Cuttings should not be allowed to dry. The best way to retain moisture is to use a daily intermittent mist. Cuttings may be maintained under natural photoperiod.

Auxin application may increase the number of cuttings that develop roots, but one may expect around $90 \%$ success without auxin. Auxin treatment may also improve some measures of root quality such as root number and root length. Several auxin sources have demonstrated success for rooting this species and include NAA (naphthaleneacetic acid); IBA (indole-3-butyric acid); and Dip 'N Grow ${ }^{\circledR}$ (Dip 'N Grow ${ }^{\circledR}$ Inc, Clackamas Oregon 97015-1888), a commercially available liquid formulation containing NAA and IBA. Homeowners will find many products containing these two active ingredients through their local garden centers. Products such as Dip 'N Grow ${ }^{\circledR}$ will have dilution ratios provided as part of the label recommendations. Commercial propagators and growers may choose NAA and IBA and dissolve these in isopropyl alcohol to prepare $10,000 \mathrm{ppm}$ stock solutions for further dilution with distilled water.

\section{Production}

The production schedule for this species in spring and summer months will begin with cuttings stuck in a pinebark-based substrate such as $100 \%$ milled pine bark or a commercial planting mix. Many commercial growers will use 72-cell trays with roots initiating within 2 to 3 weeks. Rooted cuttings are removed from the mist on week 3 or 4 and the plants remain in the propagation flats through weeks 5 to 6 . Plants are irrigated as needed 2 to 3 times each week. Nutritional status of the plants is maintained by liquid fertilization ( 1 to 2 times each week) with a $150 \mathrm{ppm}$ $\mathrm{N}$ solution from products such as Peters $20 \mathrm{~N}: 10$ $\mathrm{P}_{2} \mathrm{O}_{5}: 20 \mathrm{~K}_{2} \mathrm{O}$ (JR Peters, Inc, Allentown, PA 18106). False rosemary may be pruned in weeks 4 or 5 prior to transplant or within 1 week after transplant to initiate branching. Following transplant into 4 -inch or 1-quart pots, plants require an additional 4- to 6-week production period to achieve a full rootball and a canopy of approximately 6 to 8 inches.

\section{References}

Bell, CR and Taylor, BJ. 1982. Florida Wild Flowers and Roadside Plants. Laurel Hill Press. Chapel Hill. p. 79.

Clewel, AF. 1985. Guide to the Vascular Plants of the Florida Panhandle. University Presses of Florida, Florida State University Press. Tallahassee. p.158-159.

Thetford, Mack and Debbie Miller. 2002. Propagation of 4 Florida Coastal Dune Species. Native Plants Journal. Vol.3(2):112-120. 